\title{
Analisis Efektifitas Kerja Pengangkatan Beban Pada Bagian Pengantongan Di PT. Pupuk Krueng Geukuh
}

\author{
Muhammad Zeki*, Iskandar dan Mohd Iqbal \\ Jurusan Teknik Industri, Fakultas Teknik, Universitas Syah Kuala, Banda Aceh, Indonesia \\ *Corresponding Author : mzzzzeky@gmail.com
}

\begin{abstract}
Abstrak - Dewasa ini perkembangan teknologi sangatlah pesat, hampir semua lini kehidupan dipengaruhi oleh perkembangan teknologi. Perusahaan-perusahaan yang dulunya menggunakan tenaga manusia sekarang perlahan-lahan mulai digantikan oleh mesin-mesin yang berbasiskan teknologi komputer. Dahulu perusahaanperusahaan manufaktur hampir sepenuhnya dikerjakan oleh manusia sebagai operator mulai dari proses pengolahan bahan baku hingga produk dilepas ke pasar masih berhubungan dengan kegiatan operator. Seiring perkembangan teknologi maka tranformasi besar-besaran dari operator ke mesin-mesin yang berbasis komputerisasi pun terjadi, sehingga dampak dari permasalahan ini terjadi banyak pengangguran dimana-mana. Pesatnya perkembangan teknologi tidak serta-merta menggantikan manusia sebagai operator. Banyak kegiatan yang saat ini tetap harus dilakukan oleh manusia, diantaranya adalah proses pengangkatan beban ke suatu tempat dalam jarak yang dekat. PT. Pupuk Iskandar Muda adalah sebuah perusahaan yang bergerak dibidang pembuatan Pupuk. Produksi pupuk yang dihasilkan adalah untuk memenuhi kebutuhan pertanian dalam negeri. Sebagai negara agraris Indonesia merupakan salah satu negara yang membutuhkan pupuk untuk kebutuhan pertanian. Proses akhir dari pembuatan pupuk adalah kegiatan distribusi, pada tahap ini kegiatan muat pupuk kedalam truk adalah kegiatan penting untuk kelancaran kegiatan distribusi. Kegiatan ini dilakukan di bagian gudang pengantongan di PT.Pupuk Iskandar Muda. Kegiatan ini berlangsung secara kontinu setiap hari untuk kelancaran distribusi pupuk. Berat pupuk sebesar $50 \mathrm{~kg}$ dan diangkat secara berulang-ulang ke dalam truk dengan jumlah rata-rata untuk masing-masing truk telah berdampak kepada kesehatan operator yang mengangkat karung pupuk kedalam truk hal ini diketahui melalui pengukuran denyut jantung, penyebaran kuisioner Nordic Body Map dan wawancara langsung dengan operator yang berkerja. Masalah ini diselesaikan dengan metode pendekatan biomekanik dan pendekatan fisiologis. Akhir dari penelitian ini diperoleh rancangan alat bantu yang dapat mengatasi jarak dalam pengangkatan beban sehingga dapat mengurangi rasa sakit pada bagian-bagian tubuh operator yang melakukan kegiatan pengangkatan pupuk dari atas pallet ke dalam truk.
\end{abstract}

Kata Kunci : Efektifitas, Biomekanika, Fisiologis, Desain

\section{Pendahuluan}

Pada dasarnya setiap perusahaan selalu menginginkan agar usahanya dapat dipertahankan dan kelangsungan perusahaan dapat terjamin. Salah satu aspek penting yang menentukan tingkat kompetitif suatu perusahaan adalah bagaimana sebuah industri manufaktur dapat menjalankan produksi produksi dengan baik, dengan memperhatikan faktor-faktor produksi antara lain tenaga kerja.

Pada aktivitas produksi, umumnya ada aktivitas mengangkat (lifting), yaitu memindahkan material dari satu tempat ketempat yang lain. Sebagaimana diketahui bahwa pada perusahaan besar aktivitas mengangkat dilakukan oleh mesin, tetapi dalam hal-hal tertententu masih menggunakan manusia.

Proses pengantongan dan pengangkatan pupuk di PT. Pupuk Krueng Geukuh tidak dapat sepenuhnya dilakukan oleh mesin, tetapi masih mengandalkan tenaga manusia, diantaranya pengangkatan pupuk dari atas pallet ke dalam truk. Aktivitas angkat ini melibatkan 56 orang pekerja, mereka dibagi menjadi beberapa kelompok dengan masing-masing kelompok sebanyak 4 orang pada satu unit truk bongkar muat. Proses 
pengangkatan pupuk ini dilakukan secara berulangulang, setiap satu kantong pupuk dengan bobot seberat $50 \mathrm{~kg} / \mathrm{karung}$ diangkat oleh dua orang pekerja, dengan rata-rata pupuk yang sanggup diangkat oleh dua orang pekerja sebanyak lebih kurang sebesar 60 ton atau berjumlah sekitar 1200 kantong atau. Akibat dari pekerjaan bongkar muat ini telah menyebabkan keluhan pada tulang belakang yakni lazim disebut sakit pinggang. Bagian tulang belakang yang cenderung terkena dampak akibat bongkar muat ini adalah lumbar 5 dan sacrum 1 (L5/S1) bagian lain yang ikut terkena dampak adalah pergelangan tangan dan kaki. Pekerjaan bongkar muat ini juga berdampak pada besarnya konsumsi energi pada operator yang bekerja.

Berdasarkan permasalahan tersebut maka tujuan dari penelitian ini adalah untuk mengetahui hasil identifikasi berapa beban angkat pupuk yang aman berdasarkan NIOSH Lifting Equation di PT. Pupuk Krueng Geukuh, untuk mengetahui identifikasi bagian-bagian tubuh yang dirasa sakit oleh operator, serta mengetahui berapa jumlah konsumsi energi yang dibutuhkan dalam melakukan aktivitas mengangkat kantong pupuk dan untuk mengetahui analisis reaksi tulang belakang Lumbar 5 dan Sacrum 1 operator setelah melakukan kegiatan mengangkat kantong pupuk.

\section{Tinjauan Pustaka}

\section{Ergonomi}

Ergonomi adalah ilmu yang mempelajari interaksi antara manusia dengan elemen-elemen lain dalam suatu sistem, serta profesi yang mempraktekkan teori, prinsip, data, dan metode dalam perancangan untuk mengoptimalkan sistem agar sesuai dengan kebutuhan, kelemahan, dan keterampilan manusia.

\section{Faktor-faktor Risiko Ergonomi}

Secara garis besar, faktor-faktor ergonomi yang menyebabkan resiko MSDs dapat dipaparkan sebagai berikut:

- Repetitive Motion

- Awkward Postures

- Contact stresses

- Vibration

- Forceful extertions (termasuk lifting, pulshing, pulling)

- Duration

- Static Posture

- Physical environment; temperature \& lighting

- Other Condition

\section{Kelelahan}

Secara umum kelelahan dapat dimulai dari yang sangat ringan sampai perasaan yang sangat melelahkan. Kelelahan subyektif biasanya terjadi pada akhir jam kerja, apabila rata-rata beban kerja melebihi 30-40\% dari tenaga aerobik maksimal (Astrand \& Rodahl,1977 dan Pulat,1992).

\section{Fisiologi Kerja}

Fisiologi Kerja merupakan suatu studi tentang faktorfaktor yang mempengaruhi kinerja dan kelelahan selama otot bekerja.

\section{Kapasitas Kerja}

Ada 3 faktor yang diidentifikasi menjadi penyebab penurunan yang dialami dalam kapasitas kerja, yaitu :

a. Tuntutan fisik yang berlebihan

b. Lingkungan kerja yang berbahaya dan menimbulkan stress

c. Pengorganisasian yang buruk

\section{Kerja Fisik}

Kerja fisik akan mengeluarkan energi yang berhubungan erat dengan konsumsi energi Tuntutan fisik yang berlebihan. Konsumsi energi pada waktu kerja biasanya ditentukan dengan cara tidak langsung, yaitu dengan 2 cara sebagai berikut.

\section{Pengukuran kecepatan denyut jantung}

Peningkatan denyut nadi mempunyai peran yang sangat penting didalam peningkatan cardio output dari istirahat samapi kerja maksimum (Rodahl, 1989), didefinikan sebagai Heart Rate Reserve (HR Reserve). HR Reserve tersebut diekspresikan dalam presentase yang dihitung dengan menggunakan rumus sebagai berikut.

$\%$ HR Reserve $=\frac{\text { Denyut Nadi Kerja }- \text { Denyut Nadi Istirahat }}{\text { Denyut Nadi Maksimum }- \text { Denyut Nadi Istirahat }} \times 100$ Lebih lanjut, penentuan klasifikasi beban kerja berdasarkan peningkatan denyut nadi kerja yang dibandingkan dengan denyut nadi maksimum karena beban kardiovaskuler (cardiovasiculair atau \%CVL) yang dihitung berdasarkan rumus di bawah ini (Manuaba dan Vanwonterghem, (1996).

$\% \mathrm{CVL}=\frac{100 \times(\text { Denyut Nadi Kerja }- \text { Denyut Nadi Istirahat }}{\text { Denyut Nadi Maksimum }- \text { Denyut Nadi Istirahat }} \times 100$

Di mana denyut nadi maskimum adalah 220 dikurangi usia untuk laki-laki dan 200 dikurangi usia untuk wanita. Dari perhitungan \%CVL tersebut, kemudian akan dibandingkan dengan klasifikasi yang telah ditetapkan sebagai berikut.

Tabel 1. Klasifikasi CVL

\begin{tabular}{|c|l|}
\hline \% CVL & \multicolumn{1}{|c|}{ Klasifikasi \% CVL } \\
\hline$<30 \%$ & Tidak terjadi kelelahan \\
\hline $30 \%-60 \%$ & Diperlukan Perbaikan \\
\hline $60 \%-80 \%$ & Kerja dalam waktu singkat \\
\hline $80 \%-100 \%$ & Diperlukan tindakan segera \\
\hline$>100 \%$ & $\begin{array}{l}\text { Tidak diperbolehkan } \\
\text { beraktivitas }\end{array}$ \\
\hline
\end{tabular}

Sumber : (Proceding Seminar Nasional Industrial Services 2011: |I-81) 


\section{NIOSH Lifting Equation}

The National Institute for Occupational Safety and Health (NIOSH) sebuah lembaga yang ada di Amerika tahun 1991. Adalah lembaga yang mengeluarkan Recommended Weight Limit (RWL)yaitu merupakan rekomendasi batas beban yang dapat diangkat oleh manusia tanpa menimbulkan cidera meskipun pekerjaan tersebut dilakukan secara repetitive dan dalam jangka waktu yang cukup lama.

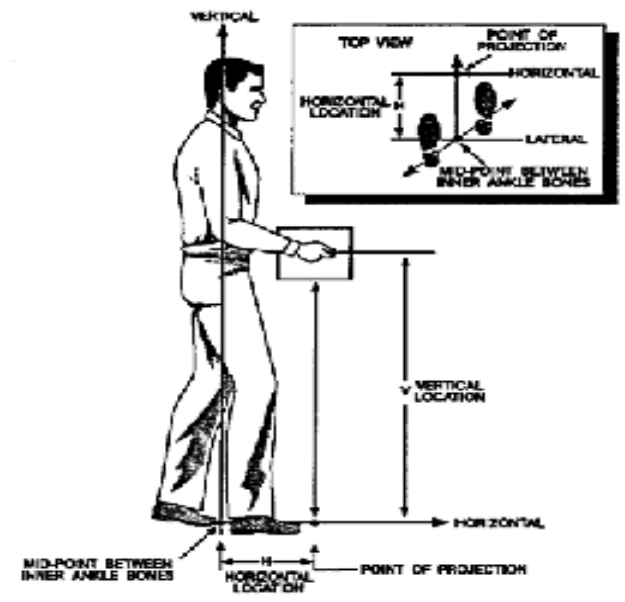

Gambar 1. Recommended Weight Limit

Persamaan untuk menentukan beban yang direkomendasikan untuk diangkat seorang pekerja dalam kondisi tertentu menurut NIOSH Lifting Equation adalah sbb:

\section{$\mathrm{RWL}=\mathrm{LC} \times \mathrm{HM} \times \mathrm{VM} \times \mathrm{DM} \times \mathrm{AM} \times \mathrm{FM} \times \mathrm{CM}$}

Keterangan:

$\mathrm{LC}=$ konstanta pembebanan

$\mathrm{HM}=$ faktor pengali horizontal

$\mathrm{VM}=$ Faktor pengali vertikal

$\mathrm{DM}=$ Faktor Pengali Jarak

$\mathrm{AM}=$ Faktor Pengali sudut

$\mathrm{FM}=$ faktor pengali frekuensi (Frequency Multiplier)

$\mathrm{CM}=$ faktor pengali kopling (handle)

Setelah nilai Recommended WeightLimit diketahui, selanjutnya perhitungan Lifting Index untuk mengetahui indeks pengangkatan yang tidak mengandung resiko cidera tulang belakang, dengan persamaan :

$$
L I=\frac{L}{R W L}
$$

Dimana : berat beban yang dipindahkan termasuk berat tempat beban

Keterangan : jika $\mathrm{LI}<=1$, maka aktivitas tersebut tidak mengandung resiko cidera tulang belakang. Jika $\mathrm{LI}>1$, maka aktivitas tersebut mengandung resiko cidera tulng belakang.

\section{Pengukuran Gaya yang bekerja di Lumbar 5 Sacrum 1}

Mekanika, merupakan studi tentang kekuatan dan pengaruhnya, bila diterapkan pada manusia, disebut biomekanik" (Jensen, 1980). Diposisikan di bawah tulang belakang dada, tulang belakang lumbar biasanya memiliki 5 vertebra, sedangkan sakrum terdiri dari serangkaian biasanya Lumbar 5 menyatu vertebra sacral (Moore, 1992). Bersama ini bagian bawah tulang belakang (lihat di bawah) disebut sebagai tulang belakang lumbo sakral dan merupakan daerah biomekanik penting dari tubuh.

Gaya yang bekerja dapat dihitung dengan contoh perhitungan sebagai berikut :

Example 1 Lifting and the Lower Back

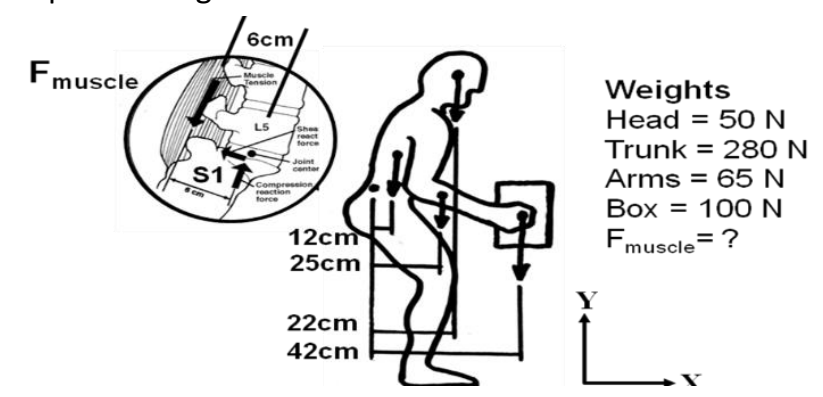

Hall 99

How much tension must be developed by erector spinae with a moment arm of $6 \mathrm{~cm}$ from the L5 - S1 joint center to maintain the body in the position shown below? (segmen weights are approximated for a 600 $\mathrm{N}(135 \mathrm{lb})$ person )

$\begin{array}{lll}\begin{array}{lll}\text { Known } \\ \text { Segment }\end{array} & \text { Wt } & \begin{array}{l}\text { Moment } \\ \text { Arm }\end{array} \\ \text { Head } & 50 \mathrm{~N} & 22 \mathrm{~cm} \\ \text { Trunk } & 280 \mathrm{~N} & 12 \mathrm{~cm} \\ \text { Arms } & 65 \mathrm{~N} & 25 \mathrm{~cm} \\ \text { Box } & 100 \mathrm{~N} & 42 \mathrm{~cm} \\ \text { Fm } & & 6 \mathrm{~cm}\end{array}$

When the body is in a static position, the sum of the torques acting at any point is zero. At L5 - S1 :

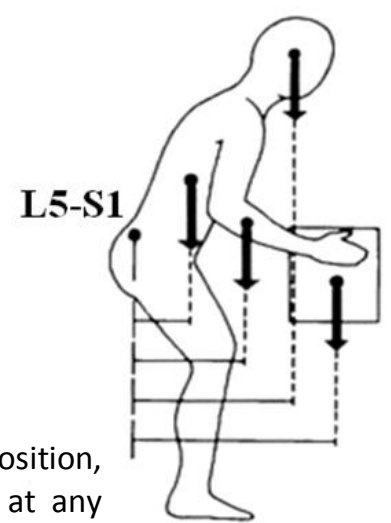

$\sum \mathrm{T}_{L 5-S 1}=0$

$0=(\mathrm{Fm})(6 \mathrm{~cm})-[(50 \mathrm{~N})(22 \mathrm{~cm})+(280 \mathrm{~N})(12$

$\mathrm{cm})+(65 \mathrm{~N})(25 \mathrm{~cm})+(100 \mathrm{~N})(42 \mathrm{~cm})$

$0=(\mathrm{Fm})(6 \mathrm{~cm})-10,285 \mathrm{~N} . \mathrm{cm}$

$\mathrm{Fm}=1714 \mathrm{~N}=2,86 \times$ Body weight

\section{Nordic Body Map}

Melalui Nordic Body Map dapat diketahui bagianbagian otot yang mengalami keluhan mulai dari rasa tidak nyaman (agak sakit) sampai tingkat sangat sakit. (tarwaka, 1985). Dengan melihat dan menganalisis Nordic Body Map akan dapat diestimasi jenis dan 
keluhan otot skeletal yang dirasakan oleh pekerja. Metode ini memberikan penilaian subjektif terhadap pekerja (Eli Mas'idah, 2009). Lembar Nordic Body Map tertera pada lampiran A Halaman 65. Untuk mengetahui besar persentase keluhan yang dirasakan, maka dapat digunakan persamaan dibawah ini :

$\underline{\text { Jumlah Jawaban pada Bobot yang Bersangkutan }} \times 100 \%$ Jumlah Seluruh Responden

\section{Metodelogi Penelitian}

Metode yang digunakan untuk menganalisis efektifitas kerja pengangkatan beban pada bagian pengantongan adalah sebagai berikut:
a. Perhitungan data kuisioner nordic body map
b. Recommended Weight Limit (RWL)
c. Energy expenditure
d. Perhitungan besar momen gaya yang terjadi pada L5/S1

\section{Hasil Dan Pembahasan}

\section{Wawancara dan Pembagian Kuesioner}

Proses pengangkutan pupuk dilakukan secara berulang-ulang, untuk 1 truk proses pengangkutan berkisar $40-50$ menit. Waktu istirahat yakni 1 jam dari jam 12.00 s.d 13.00. sampel data fisik pekerja dapat dilihat sebagai berikut :

Tabel 2. Data Fisik Operator

\begin{tabular}{|c|c|c|c|c|}
\hline No & Nama & $\begin{array}{l}\text { Berat } \\
\text { badan }\end{array}$ & $\begin{array}{l}\text { Tinggi } \\
\text { badan }\end{array}$ & Umur \\
\hline 1 & Sampel 1 & 55 & 165 & 43 \\
\hline 2 & Sampel 2 & 47 & 163 & 46 \\
\hline 3 & Sampel 3 & 65 & 176 & 40 \\
\hline 4 & Sampel 4 & 75 & 175 & 45 \\
\hline 5 & Sampel 5 & 70 & 165 & 39 \\
\hline 6 & Sampel 6 & 75 & 172 & 41 \\
\hline 7 & Sampel 7 & 60 & 166 & 35 \\
\hline 8 & Sampel 8 & 66 & 171 & 41 \\
\hline 9 & Sampel 9 & 53 & 160 & 46 \\
\hline 10 & Sampel 10 & 60 & 161 & 45 \\
\hline 11 & Sampel 11 & 58 & 170 & 35 \\
\hline 12 & Sampel 12 & 60 & 165 & 33 \\
\hline 13 & Sampel 13 & 83 & 170 & 38 \\
\hline 14 & Sampel 14 & 50 & 164 & 36 \\
\hline 15 & Sampel 15 & 65 & 165 & 38 \\
\hline 16 & Sampel 16 & 66 & 168 & 45 \\
\hline 17 & Sampel 17 & 63 & 170 & 41 \\
\hline 18 & Sampel 18 & 56 & 172 & 44 \\
\hline 19 & Sampel 19 & 55 & 164 & 36 \\
\hline 20 & Sampel 20 & 50 & 166 & 45 \\
\hline 21 & Sampel 21 & 65 & 175 & 38 \\
\hline 22 & Sampel 22 & 75 & 166 & 34 \\
\hline 23 & Sampel 23 & 59 & 167 & 37 \\
\hline 24 & Sampel 24 & 70 & 166 & 40 \\
\hline
\end{tabular}

\begin{tabular}{|l|l|l|l|l|}
25 & Sampel 24 & 52 & 160 & 45 \\
\hline 26 & Sampel 26 & 64 & 164 & 32 \\
\hline 27 & Sampel 27 & 65 & 167 & 37 \\
\hline 28 & Sampel 28 & 60 & 160 & 40 \\
\hline 29 & Sampel 29 & 48 & 140 & 35 \\
\hline 30 & Sampel 30 & 65 & 158 & 39 \\
\hline
\end{tabular}

\section{Data Fisiologi}

Data denyut jantung yang diambil dari 30 orang operator dapat dilihat pada tabel dibawah ini.

Tabel 3. Data Denyut Jantung Tiap Pekerja

\begin{tabular}{|c|c|c|c|}
\hline \multirow{2}{*}{ NO } & \multirow{2}{*}{$\begin{array}{c}\text { NAMA } \\
\text { OPERATOR }\end{array}$} & \multicolumn{2}{|c|}{$\begin{array}{l}\text { Denyut Jantung } \\
\text { (Permenit) }\end{array}$} \\
\hline & & $\begin{array}{c}\text { Sebelum } \\
\text { Kerja }\end{array}$ & $\begin{array}{l}\text { Saat } \\
\text { Kerja }\end{array}$ \\
\hline 1 & Sampel 1 & 66 & 132 \\
\hline 2 & Sampel 2 & 74,8 & 140,2 \\
\hline 3 & Sampel 3 & 58,4 & 144,6 \\
\hline 4 & Sampel 4 & 71,8 & 131,4 \\
\hline 5 & Sampel 5 & 81,8 & 131,2 \\
\hline 6 & Sampel 6 & 64,2 & 139,8 \\
\hline 7 & Sampel 7 & 78,8 & 141,2 \\
\hline 8 & Sampel 8 & 80,8 & 105,2 \\
\hline 9 & Sampel 9 & 79,8 & 122,8 \\
\hline 10 & Sampel 10 & 64 & 106,6 \\
\hline 11 & Sampel 11 & 84,4 & 139,8 \\
\hline 12 & Sampel 12 & 92,2 & 153 \\
\hline 13 & Sampel 13 & 118,6 & 124 \\
\hline 14 & Sampel 14 & 79 & 160 \\
\hline 15 & Sampel 15 & 69,8 & 137,2 \\
\hline 16 & Sampel 16 & 68,4 & 151,2 \\
\hline 17 & Sampel 17 & 70,4 & 150 \\
\hline 18 & Sampel 18 & 101,8 & 169,4 \\
\hline 19 & Sampel 19 & 68,8 & 173 \\
\hline 20 & Sampel 20 & 82,2 & 162 \\
\hline 21 & Sampel 21 & 60,2 & 163,4 \\
\hline 22 & Sampel 22 & 61,4 & 167,6 \\
\hline 23 & Sampel 23 & 66,6 & 185 \\
\hline 24 & Sampel 24 & 93,8 & 123 \\
\hline 25 & Sampel 24 & 71 & 150,6 \\
\hline 26 & Sampel 26 & 60,6 & 145 \\
\hline 27 & Sampel 27 & 84,4 & 139 \\
\hline 28 & Sampel 28 & 87,4 & 150,2 \\
\hline 29 & Sampel 29 & 66,6 & 148,8 \\
\hline 30 & Sampel 30 & 69 & 151,6 \\
\hline
\end{tabular}




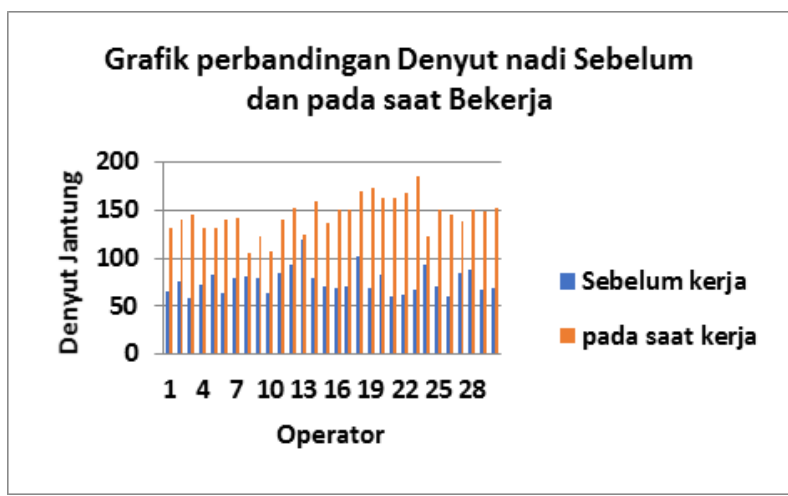

Gambar 2. Grafik Perbandingan Denyut Nadi Sebelum dan Pada saat Kerja

\section{Sistem Kerja}

Beban diangkat secara bersama-sama, setiap satu kantong pupuk diangkut oleh dua orang sehingga beban yang dipikul oleh setiap orang adalah $50 \mathrm{Kg}$ di bagi 2 sehingga nilai (LC) Load Constant yang diperoleh adalah $25 \mathrm{Kg}$. Kegiatan muat pupuk dari pallet kedalam truk dilakukan secara terus menerus dengan rata-rata truk yang dimuat berjumlah 23 ton jadwal kerja senin sampai sabtu dan jam kerja berjumlah 8 jam dan waktu istirahat yang diberikan adalah 60 menit. Kegiatan bongkar muat dapat dilihat pada gambar dibawah ini :

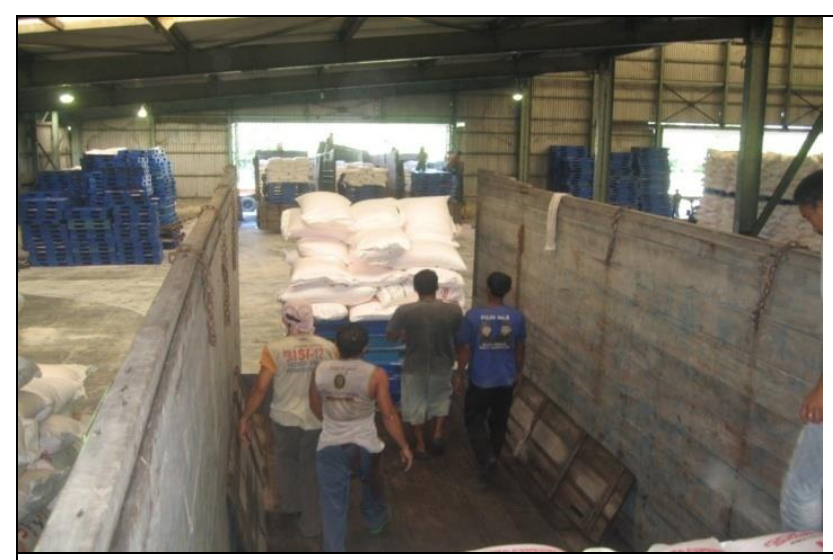

Gambar 3. Operator akan mengangkat pupuk dalam truk

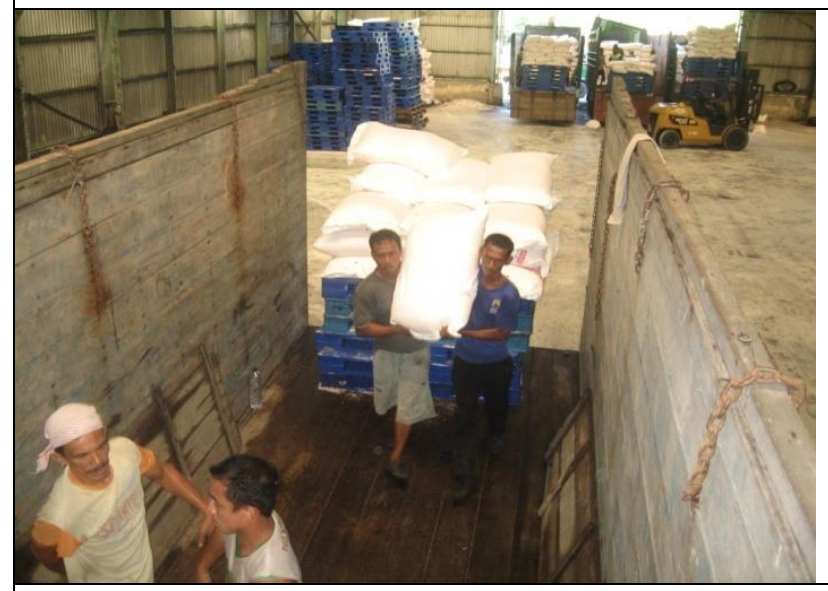

Gambar 4. Operator sedang mengangkat pupuk untuk diatur di dalam truk

\section{Beban Kerja}

Beban kerja yang menjadi objek pengamatan adalah pupuk urea yang telah dikantongi dengan berat $50 \mathrm{Kg}$ dan diletakkan di atas pallet, selanjutnya dibawa oleh forklift dan diletakkan diatas bak truk. Pekerja berada diatas bak truk mengangkat dan mengatur ke dalamnya. Pupuk yang akan dimuat ke dalam truk rata-rata sebanyak 20 ton atau 400 karung. Lihat gambar 4.2 berikut :

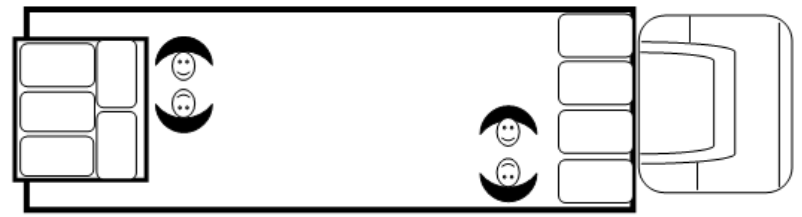

Gambar 5. Tampak atas posisi pekerja dan beban diatas pallet dalam bak truk

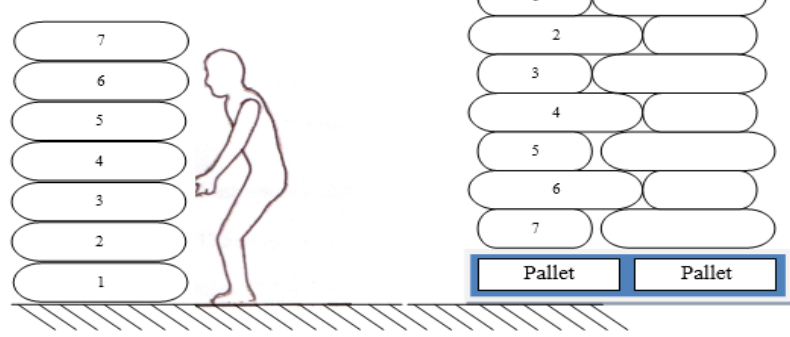

Gambar 6. Tampak samping Pupuk yang telah diangkat dan diatur di dalam bak truk

\section{Data Momen Gaya L5/S1}

Data yang digunakan untuk melakukan perhitungan momen gaya untuk masing-masing operator diperoleh berdasarkan persentase berat badan dikalikan dengan gaya gravitasi bumi $\left(10 \mathrm{~m} / \mathrm{s}^{2}\right)$. Nilai titik berat untuk body segment selengkapnya dapat dilihat pada tabel di bawah ini :

Tabel 4. Titik Berat Body Segment

\begin{tabular}{|c|c|c|c|c|c|c|}
\hline No & Operator & $\begin{array}{c}\text { Berat } \\
\text { badan } \\
(\mathrm{Kg})\end{array}$ & $\begin{array}{c}\text { W.trunk } \\
(\mathrm{N})\end{array}$ & $\begin{array}{c}\text { W.head } \\
(\mathrm{N})\end{array}$ & $\begin{array}{c}\text { W.arm } \\
(\mathrm{N})\end{array}$ & $\begin{array}{c}\text { W.beban } \\
(\mathrm{N})\end{array}$ \\
\hline 1 & Sampel 1 & 55 & 275 & 46,2 & 28,05 & 250 \\
\hline 2 & Sampel 2 & 47 & 235 & 39,48 & 23,97 & 250 \\
\hline 3 & Sampel 3 & 65 & 325 & 54,6 & 33,15 & 250 \\
\hline 4 & Sampel 4 & 75 & 375 & 63 & 38,25 & 250 \\
\hline 5 & Sampel 5 & 70 & 350 & 58,8 & 35,7 & 250 \\
\hline 6 & Sampel 6 & 75 & 375 & 63 & 38,25 & 250 \\
\hline 7 & Sampel 7 & 60 & 300 & 50,4 & 30,6 & 250 \\
\hline 8 & Sampel 8 & 66 & 330 & 55,44 & 33,66 & 250 \\
\hline 9 & Sampel 9 & 53 & 265 & 44,52 & 27,03 & 250 \\
\hline 10 & Sampel 10 & 60 & 300 & 50,4 & 30,6 & 250 \\
\hline 11 & Sampel 11 & 58 & 290 & 48,72 & 29,58 & 250 \\
\hline 12 & Sampel 12 & 60 & 300 & 50,4 & 30,6 & 250 \\
\hline 13 & Sampel 13 & 83 & 415 & 69,72 & 42,33 & 250 \\
\hline 14 & Sampel 14 & 50 & 250 & 42 & 25,5 & 250 \\
\hline
\end{tabular}




\begin{tabular}{|l|l|c|c|c|c|c|}
\hline 15 & Sampel 15 & 55 & 275 & 46,2 & 28,05 & 250 \\
\hline 16 & Sampel 16 & 66 & 330 & 55,44 & 33,66 & 250 \\
\hline 17 & Sampel 17 & 60 & 300 & 50,4 & 30,6 & 250 \\
\hline 18 & Sampel 18 & 56 & 280 & 47,04 & 28,56 & 250 \\
\hline 19 & Sampel 19 & 60 & 300 & 50,4 & 30,6 & 250 \\
\hline 20 & Sampel 20 & 50 & 250 & 42 & 25,5 & 250 \\
\hline 21 & Sampel 21 & 65 & 325 & 54,6 & 33,15 & 250 \\
\hline 22 & Sampel 22 & 75 & 375 & 63 & 38,25 & 250 \\
\hline 23 & Sampel 23 & 66 & 330 & 55,44 & 33,66 & 250 \\
\hline 24 & Sampel 24 & 70 & 350 & 58,8 & 35,7 & 250 \\
\hline 25 & Sampel 24 & 52 & 260 & 43,68 & 26,52 & 250 \\
\hline 26 & Sampel 26 & 64 & 320 & 53,76 & 32,64 & 250 \\
\hline 27 & Sampel 27 & 65 & 325 & 54,6 & 33,15 & 250 \\
\hline 28 & Sampel 28 & 62 & 310 & 52,08 & 31,62 & 250 \\
\hline 29 & Sampel 29 & 48 & 240 & 40,32 & 24,48 & 250 \\
\hline 30 & Sampel 30 & 65 & 325 & 54,6 & 33,15 & 250 \\
\hline
\end{tabular}

\section{Pengolahan Data}

Perhitungan nilai Recommended Weight Limit (RWL) tanpa alat bantu

Dari hasil pengamatan dan perhitungan diatas maka dapat dihitung Recommended Weight Limit pada bagian muat pupuk di PT.Pupuk Krueng Geukuh. Berikut rekap data variabel RWL sesuai dengan data pengamatan.

Tabel 5. Data Variabel RWL berdasarkan sistem pengangkatan pupuk dari pallet ke truk

\begin{tabular}{|c|c|c|c|c|c|c|c|}
\hline Bag & LC & HM & VM & DM & FM & AM & \multirow{2}{*}{ CM } \\
\hline No & $(\mathrm{Kg})$ & $(\mathrm{cm})$ & $(\mathrm{cm})$ & $(\mathrm{cm})$ & (detik) & (derajat) & CM \\
\hline 1 & 25 & 750 & 145 & 135 & 11,85 & $90^{\circ}$ & Poor \\
\hline 2 & 25 & 750 & 125 & 95 & 11,85 & $90^{\circ}$ & Poor \\
\hline 3 & 25 & 750 & 105 & 55 & 11,85 & $90^{\circ}$ & Poor \\
\hline 4 & 25 & 750 & 85 & 15 & 11,85 & $90^{\circ}$ & Poor \\
\hline 5 & 25 & 750 & 65 & 25 & 11,85 & $90^{\circ}$ & Poor \\
\hline 6 & 25 & 750 & 45 & 65 & 11,85 & $90^{\circ}$ & Poor \\
\hline 7 & 25 & 750 & 25 & 105 & 11,85 & $90^{\circ}$ & Poor \\
\hline
\end{tabular}

Dari tabel diatas selanjutnya dapat dibuat rekap variabel data setelah dirubah ke faktor pengali.

Tabel 6. Nilai Variabel Nilai RWL setelah dirubah ke faktor pengali

\begin{tabular}{|c|c|c|c|c|c|c|c|}
\hline Bag & LC & HM & VM & DM & FM & AM & CM \\
\hline 1 & 25 & 0,033 & 0,79 & 0,85 & 0,7 & 0,71 & 0,9 \\
\hline 2 & 25 & 0,033 & 0,85 & 0,86 & 0,7 & 0,71 & 0,9 \\
\hline 3 & 25 & 0,033 & 0,91 & 0,88 & 0,7 & 0,71 & 0,9 \\
\hline 4 & 25 & 0,033 & 0,97 & 0,91 & 0,7 & 0,71 & 0,9 \\
\hline 5 & 25 & 0,033 & 1,03 & 1,00 & 0,7 & 0,71 & 0,9 \\
\hline 6 & 25 & 0,033 & 1,09 & 1,00 & 0,7 & 0,71 & 0,9 \\
\hline 7 & 25 & 0,033 & 1,15 & 0,91 & 0,7 & 0,71 & 0,9 \\
\hline
\end{tabular}

Dengan menggunakan persamaan 3.2

$\mathrm{RWL}=\mathrm{LC} \times \mathrm{HM} \times \mathrm{VM} \times \mathrm{DM} \times \mathrm{AM} \times \mathrm{FM} \times \mathrm{CM}$

Maka diperoleh hasil Recommended Weight Limit sebagai berikut :

Tabel 7. Nilai RWL untuk pengangkatan pupuk dalam 1 pallet untuk posisi 1-7

\begin{tabular}{|c|c|}
\hline No Bag & RWL $(\mathbf{K g})$ \\
\hline 1 & 0,250 \\
\hline 2 & 0,272 \\
\hline 3 & 0,298 \\
\hline 4 & 0,329 \\
\hline 5 & 0,384 \\
\hline 6 & 0,406 \\
\hline 7 & 0,390 \\
\hline Rata-rata & 0,333 \\
\hline
\end{tabular}

Sumber : pengolahan data 2016

Hasil perhitungan Recommended Weight Limit diketahui dengan jarak HM (Horizontal Multiplier) sebesar $750 \mathrm{~cm}$ maka dapat diketahui sesuai dengan sistem kerja yang yang ada maka dapat diketahui berat beban yang aman untuk diangkat jika dilakukan secara berulang-ulang adalah rata-rata $0,33 \mathrm{Kg}$. Hal ini sangat berbanding terbalik dengan beban sebenarnya yang diangkut yakni sebesar $25 \mathrm{Kg}$. Jika hal ini tidak segera dilakukan perbaikan tentunya akan berbahaya bagi kesehatan pekerja.

Tabel 8. Kriteria dan kategori dalam pengangkatan karung pupuk

\begin{tabular}{|c|c|c|}
\hline Posisi karung pupuk & Beban (kg) & Alternatif \\
\hline $\begin{array}{l}\text { Posisi karung } \\
\text { pupuk } 1(\mathrm{t})\end{array}$ & $\begin{array}{l}\text { Karung } \\
\text { Pupuk } 25 \text { kg }\end{array}$ & $\begin{array}{l}\text { Tanpa alat } \\
\text { bantu }\end{array}$ \\
\hline $\begin{array}{l}\text { Posisi karung } \\
\text { pupuk } 2(\mathrm{t}) 125\end{array}$ & $\begin{array}{l}\text { Karung } \\
\text { Pupuk } 25 \text { kg }\end{array}$ & $\begin{array}{l}\text { Tanpa alat } \\
\text { bantu }\end{array}$ \\
\hline $\begin{array}{l}\text { Posisi karung } \\
\text { pupuk } 3(\mathrm{t}) 105\end{array}$ & $\begin{array}{l}\text { Karung } \\
\text { Pupuk } 25 \text { kg }\end{array}$ & $\begin{array}{l}\text { Tanpa alat } \\
\text { bantu }\end{array}$ \\
\hline $\begin{array}{l}\text { Posisi karung } \\
\text { pupuk } 4 \text { (t) } 85 \mathrm{~cm}\end{array}$ & $\begin{array}{l}\text { Karung } \\
\text { Pupuk } 25 \text { kg }\end{array}$ & $\begin{array}{l}\text { Tanpa alat } \\
\text { bantu }\end{array}$ \\
\hline $\begin{array}{l}\text { Posisi karung } \\
\text { pupuk } 5(\mathrm{t}) 65 \mathrm{~cm}\end{array}$ & $\begin{array}{l}\text { Karung } \\
\text { Pupuk } 25 \text { kg }\end{array}$ & $\begin{array}{l}\text { Dengan alat } \\
\text { bantu* }\end{array}$ \\
\hline $\begin{array}{l}\text { Posisi karung } \\
\text { pupuk } 6(\mathrm{t}) 45 \mathrm{~cm}\end{array}$ & $\begin{array}{l}\text { Karung } \\
\text { Pupuk } 25 \text { kg }\end{array}$ & $\begin{array}{l}\text { Dengan alat } \\
\text { bantu * }\end{array}$ \\
\hline $\begin{array}{l}\text { Posisi karung } \\
\text { pupuk } 7 \text { (t) } 25 \mathrm{~cm}\end{array}$ & $\begin{array}{l}\text { Karung } \\
\text { Pupuk } 25 \mathrm{~kg}\end{array}$ & $\begin{array}{l}\text { Dengan alat } \\
\text { bantu* }\end{array}$ \\
\hline
\end{tabular}

* posisi karung pupuk sudah dibawah pinggang operator

\section{Usulan Perancangan alat bantu kerja}

Pada penelitian tesis ini peneliti memberikan dua alternatif alat bantu kerja kepada operator yang melaksanakan proses muat pupuk ke dalam truk yakni : 
a. Troli

Troli berfungsi untuk membantu pekerja dalam mengangkat pupuk, dengan adanya troli ini, pekerja dapat memperpendek jarak Horizontal Multiplier (HM) dimana dalam pelaksanaan pengangkutan pupuk yang sebenarnya memiliki jarak lintasan maksimal untuk dipindahkan adalah sebesar $750 \mathrm{~cm}$ dengan rata-rata panjang truk 9 meter. Dengan adanya troli ini selanjutnya pupuk yang ada diatas pallet diletakkan diatas troli selanjutnya operator menarik troli sepanjang lintasan dan kemudian langsung diangkat untuk diturunkan. Dimensi troli sesuai dengan dimensi pallet namun yang membedakannya adalah setelah pallet diletakkan diatas troli ketinggiannya mencapai pinggang ratarata operator yang telah dilakukan pengukuran yakni $90 \mathrm{~cm}$.

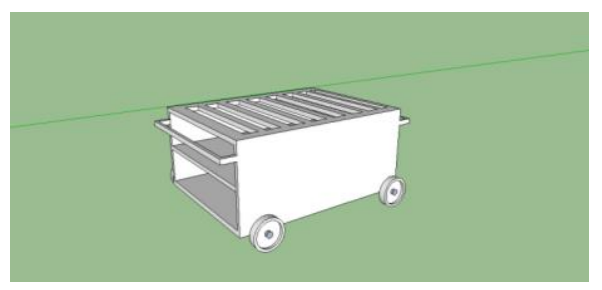

Gambar 7. Rancangan alat bantu yang akan di gunakan untuk mengangkat beban pupuk

\section{b. Conveyor}

Conveyor merupakan alternatif usulan alat bantu yang bisa digunakan untuk membantu kerja operator dalam melakukan proses pemuatan pupuk ke dalam truk conveyor.

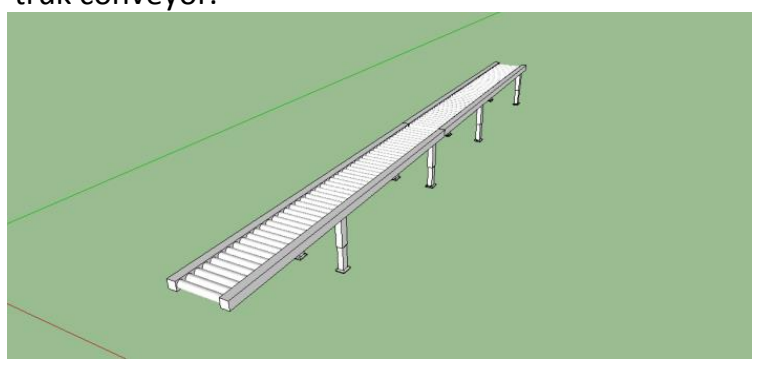

Gambar 8. Conveyor untuk alat bantu kerja operator muat pupuk

\section{Perhitungan Recommended Weight Limit (RWL) setelah adanya alat bantu kerja}

Dengan adanya alat bantu kerja selanjutnya dapat dicari Recommended Weight Limit untuk usulan dengan menggunakan alat bantu kerja. Nilai-nilai variabel yang ada sebelumnya yang terjadi perubahan adalah nilai HM (Horizontal Multiplier) yakni dengan jarak $750 \mathrm{~cm}$ berkurang menjadi $25 \mathrm{~cm}$, nilai VM dan DM terjadi perubahan dikarenakan para pekerja telah menggunakan troli dengan ketinggian $75 \mathrm{~cm}$ dan tinggi pallet $15 \mathrm{~cm}$.
Tabel 9. Data Variabel RWL berdasarkan sistem pengangkatan pupuk dari pallet ke truk

\begin{tabular}{|c|c|c|c|c|c|c|c|}
\hline $\begin{array}{c}\text { Bag } \\
\text { No }\end{array}$ & $\begin{array}{c}\mathrm{LC} \\
(\mathrm{Kg})\end{array}$ & $\begin{array}{c}\mathrm{HM} \\
(\mathrm{cm})\end{array}$ & $\begin{array}{c}\mathrm{VM} \\
(\mathrm{cm})\end{array}$ & $\begin{array}{c}\mathrm{DM} \\
(\mathrm{cm})\end{array}$ & $\begin{array}{c}\mathrm{FM} \\
(\text { detik })\end{array}$ & $\begin{array}{c}\text { AM } \\
(\text { derajat })\end{array}$ & $\mathrm{CM}$ \\
\hline 1 & 25 & 25 & 235 & 225 & 11,85 & $90^{\circ}$ & Poor \\
\hline 2 & 25 & 25 & 195 & 165 & 11,85 & $90^{\circ}$ & Poor \\
\hline 3 & 25 & 25 & 175 & 150 & 11,85 & $90^{\circ}$ & Poor \\
\hline 4 & 25 & 25 & 155 & 85 & 11,85 & $90^{\circ}$ & Poor \\
\hline 5 & 25 & 25 & 135 & 45 & 11,85 & $90^{\circ}$ & Poor \\
\hline 6 & 25 & 25 & 115 & 5 & 11,85 & $90^{\circ}$ & Poor \\
\hline 7 & 25 & 25 & 95 & 35 & 11,85 & $90^{\circ}$ & Poor \\
\hline
\end{tabular}

Selanjutnya nilai-nilai variabel diatas dilakukan dengan langkah yang sama yakni harus dirubah terlebih dahulu berdasarkan nilai pengali (faktor) yang didapat dicari dengan persamaan 3.2 dan untuk variabel FM dan AM dapat dilihat pada daftar Lampiran 1 dan 2, berikut nilai yang telah dikonversikan.

Tabel 10. Data Pupuk setelah dirubah ke faktor pengali

\begin{tabular}{|c|c|c|c|c|c|c|c|}
\hline $\begin{array}{c}\text { No } \\
\text { Bag }\end{array}$ & LC & HM & VM & DM & FM & AM & CM \\
\hline 1 & 25 & 1,0 & 0,520 & 0,84 & 0,7 & 0,71 & 0,9 \\
\hline 2 & 25 & 1,0 & 0,850 & 0,85 & 0,7 & 0,71 & 0,9 \\
\hline 3 & 25 & 1,0 & 0,910 & 0,85 & 0,7 & 0,71 & 0,9 \\
\hline 4 & 25 & 1,0 & 0,970 & 0,87 & 0,7 & 0,71 & 0,9 \\
\hline 5 & 25 & 1,0 & 1,030 & 0,92 & 0,7 & 0,71 & 0,9 \\
\hline 6 & 25 & 1,0 & 1,090 & 0,90 & 0,7 & 0,71 & 0,9 \\
\hline 7 & 25 & 1,0 & 1,150 & 0,95 & 0,7 & 0,71 & 0,9 \\
\hline
\end{tabular}

Sumber : pengolahan data 2016

Perhitungan lengkap untuk hasil RWL keseluruhan pupuk 1 sampai dengan 7 dapat kita lihat pada tabel 4.6 berikut ini :

Tabel 11. Perhitungan Recommended Weight Limit

\begin{tabular}{|c|c|}
\hline No Bag & RWL \\
\hline 1 & 4,885 \\
\hline 2 & 8,053 \\
\hline 3 & 8,650 \\
\hline 4 & 9,469 \\
\hline 5 & 10,597 \\
\hline 6 & 10,992 \\
\hline 7 & 12,199 \\
\hline
\end{tabular}

Sumber : pengolahan data 2016

Dari tabel diatas bisa dilihat bahwa beban sangat berpengaruh terhadap jarak vertikal multiplier dan jarak distance multiplier. Jarak vertikal multiplier dan distance multiplier yang nilainya semakin besar maka akan memberikan nilai beban angkat yang semakin kecil kepada operator. 


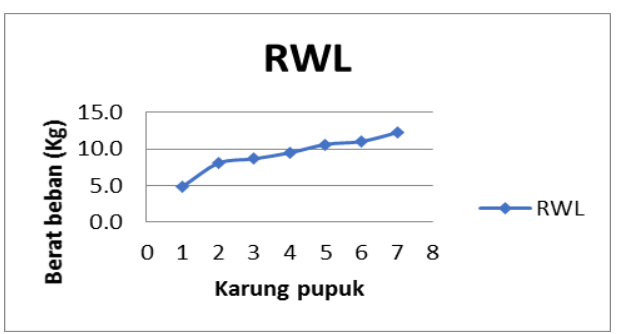

Gambar 9. Grafik beban pengangkatan pupuk

\section{Perhitungan Lifting Indeks (니)}

Nilai Recommended Weight Limit (RWL) yang diperoleh selanjutnya dapat kita gunakan untuk menghitung Lifting Indeks (LI)

Tabel 12. Perhitungan Lifting Indeks

\begin{tabular}{|c|c|c|c|}
\hline No & LC & RWL & LI=LC/RWL \\
\hline 1 & 25 & 4,885 & 5,12 \\
\hline 2 & 25 & 8,053 & 3,10 \\
\hline 3 & 25 & 8,650 & 2,89 \\
\hline 4 & 25 & 9,469 & 2,64 \\
\hline 5 & 25 & 10,597 & 2,36 \\
\hline 6 & 25 & 10,992 & 2,27 \\
\hline 7 & 25 & 12,199 & 2,05 \\
\hline
\end{tabular}

\section{Perhitungan hasil kuesioner nordic body map}

Setelah mendapatkan hasil dari jawaban yang diperoleh pada saat penyebaran kuesioner dan dengan menggunakan persamaan 3.1 maka akan diperoleh hasil persentase keluhan sakit pada tiap-tiap bagian tubuh operator.

Tabel 13. Rekapitulasi Kuisioner Nordic Body Map

\begin{tabular}{|c|c|c|c|c|c|c|c|}
\hline \multirow[t]{2}{*}{ No } & \multirow[t]{2}{*}{ Lokasi } & \multicolumn{4}{|c|}{ Tingkat Kesakitan } & Peta & \multirow{2}{*}{ Bagian } \\
\hline & & A & B & $C$ & $\mathrm{D}$ & & \\
\hline 0 & $\begin{array}{l}\text { Sakit / kaku } \\
\text { pada leher atas }\end{array}$ & 27 & 3 & & & & \\
\hline 1 & $\begin{array}{l}\text { Sakit pada leher } \\
\text { bawah }\end{array}$ & & 23 & 7 & & & \\
\hline 2 & $\begin{array}{l}\text { Sakit pada bahu } \\
\text { kiri }\end{array}$ & & 20 & 10 & & & \\
\hline 3 & $\begin{array}{l}\text { Sakit pada bahu } \\
\text { kanan }\end{array}$ & & 20 & 10 & & & $1+2-7$ \\
\hline 4 & $\begin{array}{l}\text { Sakit pada } \\
\text { lengan atas kiri }\end{array}$ & & 7 & 23 & & & \\
\hline 5 & $\begin{array}{l}\text { Sakit pada } \\
\text { punggung }\end{array}$ & & 4 & 26 & & & \\
\hline 6 & $\begin{array}{lr}\text { Sakit } & \text { pada } \\
\text { lengan } & \text { atas }\end{array}$ & & 7 & 23 & & & \\
\hline 7 & $\begin{array}{l}\text { Sakit pada } \\
\text { pinggang }\end{array}$ & & 28 & 2 & & & \\
\hline
\end{tabular}

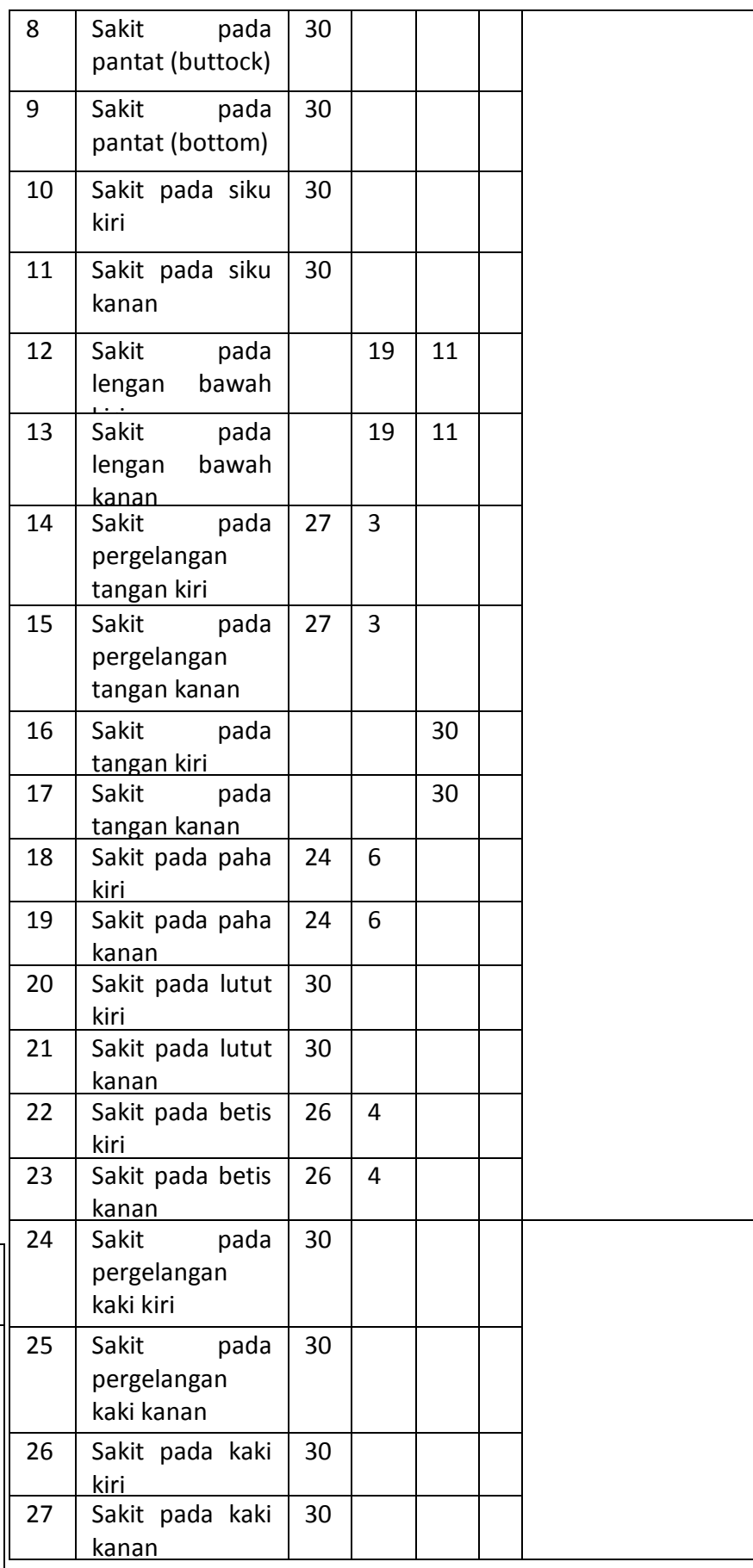

Sumber : pengolahan data

Perhitungan persentase untuk kondisi tanpa keluhan sakit.

Tabel 14. Persentase pengolahan data kuesioner Nordic Body Map

\begin{tabular}{|c|l|c|c|c|c|c|c|c|c|}
\hline \multirow{2}{*}{ No } & \multirow{2}{*}{ Lokasi } & \multicolumn{3}{|c|}{ Tingkat Kesakitan } & \multicolumn{5}{|c|}{ Persentase } \\
\cline { 3 - 11 } & & A & B & C & D & A & B & C & D \\
\hline 0 & Sakit & 27 & 3 & & & 90 & 10 & & \\
\hline 1 & Sakit & & 23 & 7 & & & 76 & 23 & \\
\hline 2 & Sakit & & 20 & 10 & & & 66 & 33 & \\
\hline 3 & Sakit & & 20 & 10 & & & 66 & 33 & \\
\hline 4 & Sakit & & 7 & 23 & & & 23 & 76 & \\
\hline
\end{tabular}




\begin{tabular}{|c|l|l|c|c|c|c|c|c|c|}
5 & Sakit & & & 4 & 26 & & 0 & 13 & 86, \\
\hline 6 & Sakit & & 7 & 23 & & & 23 & 76 & \\
\hline 7 & Sakit & & & 2 & 28 & & & 6, & 93, \\
\hline 8 & Sakit & 30 & & & & 10 & & & \\
\hline 9 & Sakit & 30 & & & & 10 & & & \\
\hline 10 & Sakit & 30 & & & & 10 & & & \\
\hline 11 & Sakit & 30 & & & & 10 & & & \\
\hline 12 & Sakit & & 19 & 11 & & & 63 & 36 & \\
\hline 13 & Sakit & & 19 & 11 & & & 63 & 36 & \\
\hline 14 & Sakit & 27 & 3 & & & 90 & 10 & & \\
\hline 15 & Sakit & 27 & 3 & & & 90 & 10 & & \\
\hline 16 & Sakit & & & 30 & & & & 10 & \\
\hline 17 & Sakit & & & 30 & & & & 10 & \\
\hline 18 & Sakit & 24 & 6 & & & 80 & 20 & & \\
\hline 19 & Sakit & 24 & 6 & & & 80 & 20 & & \\
\hline 20 & Sakit & 30 & & & & 10 & & & \\
\hline 21 & Sakit & 30 & & & & 10 & & & \\
\hline 22 & Sakit & 26 & 4 & & & 86 & 13 & & \\
\hline 23 & Sakit & 26 & 4 & & & 86 & 13 & & \\
\hline 24 & Sakit & 30 & & & & 10 & & & \\
\hline 25 & Sakit & 30 & & & & 10 & & & \\
\hline 26 & Sakit & 30 & & & & 10 & & & \\
\hline 27 & Sakit & 30 & & & & 10 & & & \\
\hline
\end{tabular}

Sumber : Pengolahan Data

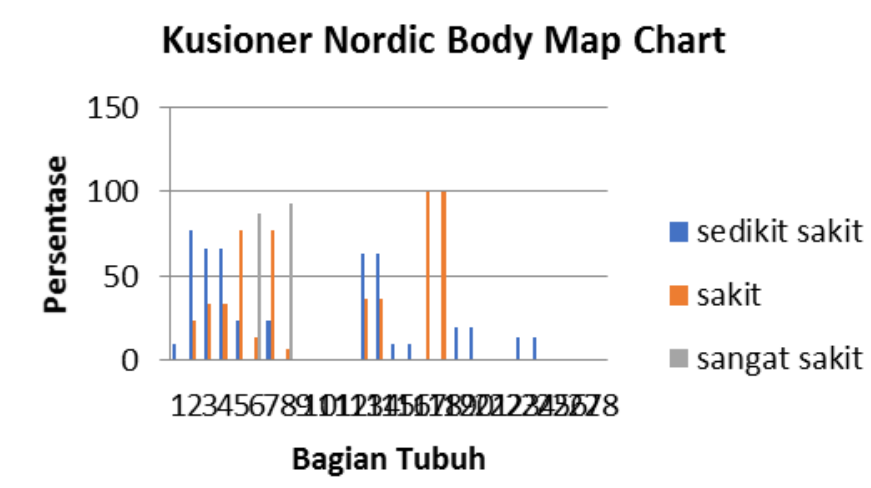

Gambar 10. Grafik Persentase Hasil Kuisioner

\section{Pengolahan data Fisiologi}

Jumlah konsumsi energi untuk operator 2 dan seterusnya dapat dilihat pada tabel berikut :

Tabel 15. Jumlah Konsumsi Energi dan Penggolongan

\section{Beban Kerja}

\begin{tabular}{|c|c|c|c|c|c|c|c|}
\hline \multirow[b]{2}{*}{ NO } & \multirow[b]{2}{*}{ NAMA } & \multicolumn{2}{|c|}{ Denyut Nadi } & \multirow[b]{2}{*}{$Y w$} & \multirow[b]{2}{*}{$\mathrm{Yr}$} & \multirow[b]{2}{*}{ ER } & \multirow{2}{*}{$\begin{array}{l}\text { Tingketrgi } \\
\text { Pekeriaan } \\
\text { Rekapi }\end{array}$} \\
\hline & & $\begin{array}{l}\text { Sebelum } \\
\text { bekerja }\end{array}$ & $\begin{array}{l}\text { Setelah } \\
\text { bekerja }\end{array}$ & & & & \\
\hline 1 & Sampel 1 & 66 & 132 & 7,00 & 2,35 & 6,48 & Mosla \\
\hline 2 & Sampel 2 & 74,8 & 140,2 & 7,87 & 2,73 & 7,29 & lodera \\
\hline 3 & Sampel 3 & 58,4 & 144,6 & 8,36 & 2,08 & 7,66 & teavy \\
\hline 4 & Sampel 4 & 71,8 & 131,4 & 6,94 & 2,59 & 6,46 & Moderate \\
\hline 5 & Sampel 5 & 81,8 & 131,2 & 6,92 & 3,09 & 6,49 & Moderat \\
\hline 6 & Sampel 6 & 64,2 & 139,8 & 7,82 & 2,28 & 7,21 & Moderat \\
\hline 7 & Sampel 7 & 78,8 & 141,2 & 7,98 & 2,93 & 7,41 & Moderat \\
\hline
\end{tabular}

\begin{tabular}{|l|l|l|l|l|l|l|l|}
\hline 8 & Sampel 8 & 80,8 & 105,2 & 4,62 & 3,03 & 4,44 & Light \\
\hline 9 & Sampel 9 & 79,8 & 122,8 & 6,11 & 2,98 & 5,76 & Moderate \\
\hline 10 & Sampel 10 & 64 & 106,6 & 4,72 & 2,27 & 4,45 & Light \\
\hline 11 & Sampel 11 & 84,4 & 139,8 & 7,82 & 3,23 & 7,31 & Moderate \\
\hline 12 & Sampel 12 & 92,2 & 153 & 9,34 & 3,70 & 8,72 & Heavy \\
\hline 13 & Sampel 13 & 118,6 & 124 & 6,22 & 5,72 & 6,16 & Moderate \\
\hline 14 & Sampel 14 & 79 & 160 & 10,22 & 2,94 & 9,41 & Heavy \\
\hline 15 & Sampel 15 & 69,8 & 137,2 & 7,54 & 2,50 & 6,98 & Moderate \\
\hline 16 & Sampel 16 & 68,4 & 151,2 & 9,13 & 2,44 & 8,38 & Heavy \\
\hline 17 & Sampel 17 & 70,4 & 150 & 8,98 & 2,53 & 8,27 & Heavy \\
\hline 18 & Sampel 18 & 101,8 & 169,4 & 11,46 & 4,36 & 10,67 & V. Heavy \\
\hline 19 & Sampel 19 & 68,8 & 173 & 11,96 & 2,46 & 10,90 & V.Heavy \\
\hline 20 & Sampel 20 & 82,2 & 162 & 10,47 & 3,11 & 9,66 & Heavy \\
\hline 21 & Sampel 21 & 60,2 & 163,4 & 10,66 & 2,13 & 9,71 & Heavy \\
\hline 22 & Sampel 22 & 61,4 & 167,6 & 11,22 & 2,18 & 10,21 & V. Heavy \\
\hline 23 & Sampel 23 & 66,6 & 185 & 13,71 & 2,37 & 12,45 & V. Heavy \\
\hline 24 & Sampl 24 & 93,8 & 123 & 6,12 & 3,81 & 5,87 & Moderate \\
\hline 25 & Sampel 24 & 71 & 150,6 & 9,05 & 2,56 & 8,33 & Heavy \\
\hline 26 & Sampel 26 & 60,6 & 145 & 8,40 & 2,15 & 7,71 & Veavy \\
\hline 27 & Sampel 27 & 84,4 & 139 & 7,73 & 3,23 & 7,23 & Moderate \\
\hline 28 & Sampel 28 & 87,4 & 150,2 & 9,01 & 3,41 & 8,38 & Heavy \\
\hline 29 & Sampel 29 & 66,6 & 148,8 & 8,84 & 2,37 & 8,12 & Heavy \\
\hline 30 & Sampel 30 & 69 & 151,6 & 9,17 & 2,47 & 8,43 & Heavy \\
\hline
\end{tabular}

Sumber : Pengolahan Data

Dari hasil pengolahan data diatas maka dapat kita lihat hasil perbandingan konsumsi energi sebelum dan sesudah operator melakukan pekerjaan bongkar muat pada grafik dibawah ini :

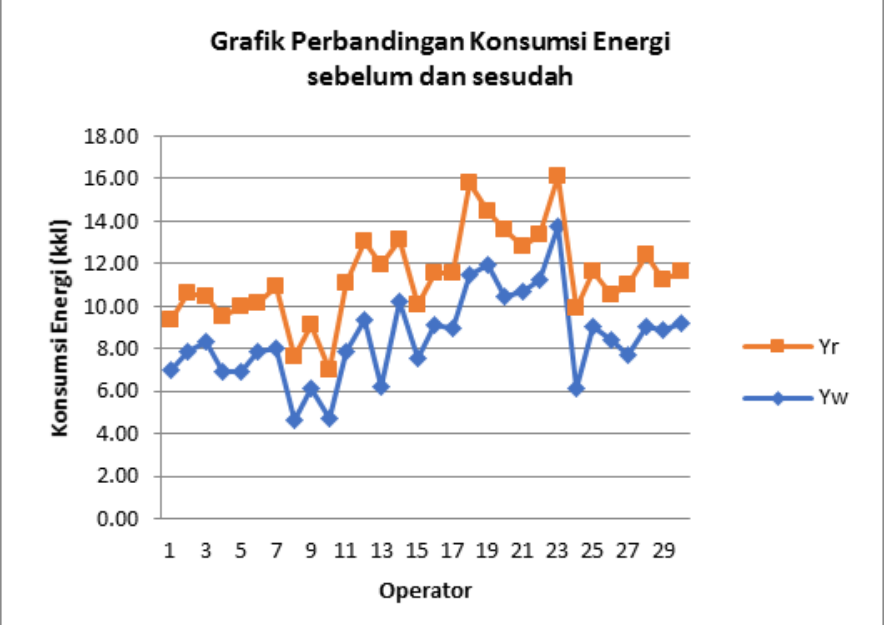

Gambar 11. Grafik perbandingan konsumsi energi sebelum dan sesudah bekerja

Perhitungan Waktu Istirahat.

Dari hasil pengolahan terhadap jumlah konsumsi

gketrgi yang dibutuhkan oleh seorang operator, Rekapitulasi perhitungan waktu istirahat untuk 30 orang amatpel operator dapat dilihat pada tabel dibawah ini. 
Tabel 16. Rekapitulasi waktu istirahat yang dibutuhkan untukmasing-masing operator

\begin{tabular}{|c|c|c|c|}
\hline No & Nama & $\begin{array}{c}\text { Waktu } \\
\text { Kerja }\end{array}$ & $\begin{array}{l}\text { Waktu } \\
\text { Istirahat }\end{array}$ \\
\hline 1 & Sampel 1 & 240 & 101,7 \\
\hline 2 & Sampel 2 & 240 & 157,4 \\
\hline 3 & Sampel 3 & 240 & 182,3 \\
\hline 4 & Sampel 4 & 240 & 99,9 \\
\hline 5 & Sampel 5 & 240 & 102,4 \\
\hline 6 & Sampel 6 & 240 & 151,3 \\
\hline 7 & Sampel 7 & 240 & 165,6 \\
\hline 8 & Sampel 8 & 240 & $-38,4$ \\
\hline 9 & Sampel 9 & 240 & 52,0 \\
\hline 10 & Sampel 10 & 240 & $-37,7$ \\
\hline 11 & Sampel 11 & 240 & 158,5 \\
\hline 12 & Sampel 12 & 240 & 254,8 \\
\hline 13 & Sampel 13 & 240 & 79,7 \\
\hline 14 & Sampel 14 & 240 & 302,2 \\
\hline 15 & Sampel 15 & 240 & 135,9 \\
\hline 16 & Sampel 16 & 240 & 232,0 \\
\hline 17 & Sampel 17 & 240 & 223,9 \\
\hline 18 & Sampel 18 & 240 & 389,0 \\
\hline 19 & Sampel 19 & 240 & 404,9 \\
\hline 20 & Sampel 20 & 240 & 319,2 \\
\hline 21 & Sampel 21 & 240 & 323,0 \\
\hline 22 & Sampel 22 & 240 & 357,4 \\
\hline 23 & Sampel 23 & 240 & 511,0 \\
\hline 24 & Sampel 24 & 240 & 59,4 \\
\hline 25 & Sampel 24 & 240 & 228,5 \\
\hline 26 & Sampel 26 & 240 & 185,6 \\
\hline 27 & Sampel 27 & 240 & 153,2 \\
\hline 28 & Sampel 28 & 240 & 232,0 \\
\hline 29 & Sampel 29 & 240 & 214,1 \\
\hline 30 & Sampel 30 & 240 & 235,1 \\
\hline \multicolumn{3}{|c|}{ Rata-rata } & 197,9 \\
\hline
\end{tabular}

Sumber : pengolahan data

\section{Perhitungan Momen Gaya yang Terjadi pada L5/S1}

Momen gaya yang yang bekerja pada L5/S1 untuk semua operator dapt dilihat pada tabel berikut dibawah ini :

Tabel 17. Momen gaya yang bekerja pada L5/S1 untuk masing-masing operator

\begin{tabular}{|c|l|c|}
\hline No & \multicolumn{1}{|c|}{ Operator } & Fm \\
\hline 1 & Sampel 1 & 3819,4 \\
\hline 2 & Sampel 2 & 3782,9 \\
\hline 3 & Sampel 3 & 4296,5 \\
\hline 4 & Sampel 4 & 4386,9 \\
\hline 5 & Sampel 5 & 4257,6 \\
\hline 6 & Sampel 6 & 4503,7 \\
\hline 7 & Sampel 7 & 4046,4 \\
\hline 8 & Sampel 8 & 4042,3 \\
\hline 9 & Sampel 9 & 3752,2 \\
\hline
\end{tabular}

\begin{tabular}{|c|c|c|}
\hline 10 & Sampel 10 & 3886,6 \\
\hline 11 & Sampel 11 & 3966,3 \\
\hline 12 & Sampel 12 & 3975,1 \\
\hline 13 & Sampel 13 & 4530,3 \\
\hline 14 & Sampel 14 & 3634,7 \\
\hline 15 & Sampel 15 & 3881,0 \\
\hline 16 & Sampel 16 & 4026,0 \\
\hline 17 & Sampel 17 & 4077,8 \\
\hline 18 & Sampel 18 & 4128,1 \\
\hline 19 & Sampel 19 & 3894,4 \\
\hline 20 & Sampel 20 & 3684,4 \\
\hline 21 & Sampel 21 & 4303,5 \\
\hline 22 & Sampel 22 & 4081,0 \\
\hline 23 & Sampel 23 & 4014,2 \\
\hline 24 & Sampel 24 & 4029,3 \\
\hline 25 & Sampel 24 & 3741,6 \\
\hline 26 & Sampel 26 & 3864,5 \\
\hline 27 & Sampel 27 & 3923,9 \\
\hline 28 & Sampel 28 & 4016,1 \\
\hline 29 & Sampel 29 & 3554,4 \\
\hline 30 & Sampel 30 & 3990,4 \\
\hline
\end{tabular}

Sumber : pengolahan data

Berdasarkan hasil penelitian yang dilakukan oleh NIOSH institute tentang penetapan batas momen gaya maksimum L5/S1 yang diperbolehkan yakni sebesar $3400 \mathrm{~N}$, maka dapat diambil kesimpulan hasil yang diperoleh terhadap momen gaya yang bekerja untuk semua operator adalah sudah melebihi batas maksimum yang diperbolehkan. Momen gaya yang bekerja pada L5/S1 rata-rata 5780,2 N nilai ini memiliki selisih sebesar 2380,2 N dari standar momen gaya yang telah ditetapkan.

Besarnya nilai momen gaya yang bekerja pada L5/S1 untuk masing-masing operator dipengaruhi oleh postur kerja yang dinamis, dimana operator harus membungkuk dan harus berjalan untuk membawa beban untuk di susun di dalam truk. Untuk mengurangi resiko terjadinya cedera pada tulang belakang khususnya pada bagian L5/S1 adalah dengan melakukan perbaikan kerja dan bila perlu diciptakan alat bantu untuk mencegah operator membungkuk dalam mengangkat beban.

Hasil Perhitungan Recommended Wight Limit (RWL) Faktual menunjukkan bahwa beban rata-rata yang dapat diangkat oleh operator adalah sebesar $0,33 \mathrm{Kg}$, hasil ini sesuai dengan kondisi kerja yang dilakukan sebelum dilakukan perbaikan. Setelah dilakukan perbaikan dengan menggunakan alat bantu maka terjadi peningkatan yang signifikan dengan menggunakan troli beban yang dapat diangkat jadi dapat bertambah menjadi beban minimal yang dapat diangkat pada posisi paling atas adalah $4,885 \mathrm{Kg}$ dan beban maksimal yang dapat diangkat adalah 12,19 ini dikarenakan operator 
mengangkat beban tidak langsung diatas lantai tetapi diatas troli dengan ukuran pinggang rata-rata orang dewasa.

Pekerjaan bongkar muat ini juga dapat digolongkan ke dalam beberapa kategori pekerjaan untuk masingmasing pekerja atau operator. Beberapa operator digolongkan ke dalam kategori Light, Moderate, Heavy dan Very Heavy. Hasil ini diperoleh setelah dilakukan jumlah penghitungan konsumsi energi untuk 30 orang operator berdasarkan denyut jantung setelah dan sebelum bekerja.

Setelah dilakukan perhitungan waktu istirahat maka untuk setiap operator dibutuhkan waktu istirahat ratarata sebesar 197,9 menit. Waktu istirahat ini dibutuhkan setelah operator bekerja selama 4 jam atau 240 menit. Waktu istirahat yang diperoleh sangat jauh berbeda dengan kondisi sebenarnya, dimana sebelumnya operator hanya mendapat waktu istirahat selama 60 menit dalam satu hari kerja.

\section{Kesimpulan}

Dari hasil penelitian yang telah dilakukan di bagian bongkar muat PT. Pupuk Krueng Geukuh, setelah dilakukan pembahasan maka dapat ditarik kesimpulan sebagai berikut :

1. Perhitungan recommended weight limit faktual tanpa alat bantu diperoleh nilai batas beban yang dapat diangkat rata-rata sebesar $0,33 \mathrm{Kg}$, namun setelah dilakukan perbaikan kerja dengan menggunakan alat bantu maka batas beban minimal yang dapat diangkat adalah $4,885 \mathrm{Kg}$ hal ini disebabkan posisi angkat dimulai dari posisi paling atas sedangkan beban maksimal adalah $12,19 \mathrm{Kg}$ peningkatan ini terjadi karena operator mengangkat dimulai dari batas pinggang rata-rata orang dewasa.

2. Hasil rekapitulasi kuesioner nordic body map diperoleh hasil bahwa persentase terbesar yang mengalami keluhan terjadi pada bagian punggung dan pinggang yakni dengan persentase sebesar $86,7 \%$ dan 9,33\%.

3. Pekerjaan bongkar muat di PT.Pupuk Krueng Geukuh digolongkan kepada beberapa kategori kerja yakni kategori Light, Moderate, Heavy, Very Heavy, dari 30 orang sampel yang diamati terdapat 2 orang bekerja dengan kondisi Light, 12 orang bekerja dengan kondisi Moderate (sedang), 12 orang bekerja dengan kondisi Heavy (berat) dan 4 orang bekerja dengan kondisi Very Heavy (sangat berat).

4. Desain alat bantu dalam penelitian ini berupa meja kerja yang dapat bergerak fleksibel maju dan mundur yang dapat ditempatkan di dalam truk yang melakukan bongkar muat.

\section{Daftar Pustaka}

[1] Achiraenawati, Erri.2004. Analisis Aspek Ergonomic pada pemindahan material secara manual berdasarkan NIOSH formula sebagai upaya keamanan dan keselamatan kerja. penerbit Fakultas Teknik Universitas Islam. Bandung.

[2] Khalid,Thoha. 2009.Analisis resiko Ergonomi dan Keluhan Muskuloskeletal pada upper Limb Extrimities Akibat Penggunaan Laptop pada Mahasiswa S1 FKM UI. FKM UI.

[3] Kuswana, S.W, 2016. Ergonomi dan Kesehatan dan Keselamatan Kerja. Edisi ke-2.Rosdakarya Bandung.

[4] Nurmianto, Eko.1998 Ergonomi Konsep Dasar dan Aplikasinya, Penerbit Guna Widya. Jakarta.

[5] National Institute Occupational Health and Safety, Calculating Recomended Weight Limit. www.ccosh.ca/inguiris_form html.

[6] Prassetiyo Hendro, Jurnal Penelitian, Program Studi Teknik Mesin dan Teknik Industri Jurusan Teknik Mesin Fakultas Teknik Universitas Tarumanagara, 2010.

[7] Sutalaksana, Z Iftikar.Anggawisastra, R, Tjakraatmaja, J.H.1979Teknik Tata Cara Kerja. Penerbit Jurusan Teknik Industri Institut Teknologi Bandung.

[8] Simanjuntak, A.R. 2011.Penilaian Resiko Manual Handling dengan Metode Indikator Kunci dan Penentuan Klasifikasi Beban Kerja dengan Penentuan Cardiovaskular Load.Penerbit Jurusan Teknik Industri Institut Sains dan Teknologi AKPRIND Yogyakarta.

[9] Tarwaka. 2006. Ergonomi untuk Kesehatan dan Keselamatan Kerja. Penerbit Institut Teknologi Bandung.

[10] Veronica. 2001. Laporan Resmi Praktikum Ergonomi. Penerbit Jurusan Teknik Industri Institut Teknologi Sepuluh Nopember. Surabaya.

[11] Zeki,Muhammad. 2007. Penentuan Batas Angkat Pupuk yang aman pada Bagian Pengantongan di PT.Pupuk Iskandar Muda, Universitas Malikussaleh, Lhokseumawe. 
